\title{
EFFECT OF CALCIUM CARBONATE FILLER AND ALKALI TREATMENT ON PHYSICAL AND ELASTIC PROPERTIES OF JUTE MAT REINFORCED POLYESTER RESIN COMPOSITES
}

\author{
Rahima Nasrin $^{1,2 *}$, Salma Begum ${ }^{2}$, M. A. Gafur ${ }^{3}$, A. H. Bhuiyan ${ }^{2}$ \\ ${ }^{1}$ Department of Physics, University of Barisal, Barisal 8200, Bangladesh \\ ${ }^{2}$ Department of Physics, Bangladesh University of Engineering and Technology (BUET), Dhaka \\ 1000, Bangladesh \\ ${ }^{3}$ Pilot Plant \& Process Development Centre, Bangladesh Council of Scientific \& Industrial \\ Research (BCSIR), Dhaka, Bangladesh \\ *Corresponding author e-mail: muktanasrin77@gmail.com
}

Received on 21.12.2019, Revised received on 20.02.2020, Accepted for publication on 22.02.2020

\begin{abstract}
Polyester resin-jute mat reinforced composites with different wt $\%$ of calcium carbonate $\left(\mathrm{CaCO}_{3}\right)$ filler were fabricated using a simple cold press molding method. The effects of $\mathrm{CaCO}_{3}$ filler and alkali $(\mathrm{NaOH})$ treatment on various physical and elastic properties were evaluated. Water absorption (WA) increases with the increase of soaking time and load. The maximum WA was observed for $5 \mathrm{wt} \%$ addition of $\mathrm{CaCO}_{3}$ and for more $\mathrm{CaCO}_{3}$, WA decreases. The ultimate tensile strength (UTS) and flexural strength (FS) decreases with the addition of $\mathrm{CaCO}_{3}$ for $0.5 \mathrm{wt} \% \mathrm{NaOH}$ treated composites but for $5 \mathrm{wt} \% \mathrm{NaOH}$ treated composites UTS and FS increases with the addition of $\mathrm{CaCO}_{3}$ filler. The optimum filler addition is about $5 \mathrm{wt} \% \mathrm{CaCO}_{3}$. With the addition of $\mathrm{CaCO}_{3}$, tangent modulus increases for $0.5 \mathrm{wt} \% \mathrm{NaOH}$ treated composites and for $5 \mathrm{wt} \% \mathrm{NaOH}$ treated composites it increases up to a maximum value and then decreases. The effect of load on tensile and flexural properties is also discussed.
\end{abstract}

Keywords: Calcium Carbonate, Jute Mat, Elastic Properties, Composite

\section{INTRODUCTION}

Nowadays, scientists and engineers working in the field of materials are very much concerned with sustainability issues and environmental protection. Therefore, environmental friendly, natural, biodegradable materials are attracting lot of interest among them. Because of environmental friendly, biodegradability and sustainability nature, natural fiber composites are preferred as compared to conventional synthetic fiber based composites [1]. Natural fiber from plants such as jute, bamboo, coir, sisal and pineapples are known to have very high strength and hence can be effectively utilized for many load-bearing applications. These fibers have special advantages over other synthetic fibers because they are abundantly biodegradable. At the same time they have low density, high toughness and acceptable specific strength properties. They also show reduced tool wear, reduced dermal and respiratory irritation and good thermal properties [2]. Among all the natural fiber reinforced materials jute appears to be a promising material, because it is relatively inexpensive and commercially available in many forms [3]. Bangladesh has a long history of jute fiber production and jute fiber is mainly used for producing gunny bags, carpet backing, ropes etc. 
Jute fiber reinforced composites has lead to an increasing interest for high value added products, such as in household, packing, structural materials for housing, railways, automobiles products, piping etc. The idea of producing long lasting composite materials made of jute fibers has not been considered in the past because of its rotting, swelling and burning properties. It is now found that application of jute fibers for composites has many advantages. Jute fiber is versatile, non-abrasive, biodegradable and compatible [4-7]. Ray et al. [8] investigated on mechanical behavior of untreated and alkali treated jute fiber reinforced vinyl ester composites. They reported that longer alkali treatment removed the hemicelluloses and improved the crystallinity and gave better fiber dispersion. For $35 \mathrm{wt} \%$ jute/vinyl ester composites containing both untreated and alkali treated fibers, the flexural strength (FS) of the composite made from treated fiber was superior. Four hour alkali treated jute fibers gave the optimum combination of improved interfacial bonding and fiber strength properties. Islam et al. [9] studied on structural and mechanical behavior of PP-jute blends and showed that alkali treated jute reinforced have much better properties than the untreated properties one. SEM observations indicated good interfacial contact between the short fiber and PP matrix. TG/DTG revealed that the introduction of short jute fiber led to a slightly improved thermo oxidative stability of PP-jute composites. Ray et al. [10] reported the mechanical and thermal behavior of vinyl ester-resin-matrix composites reinforced with untreated and $5 \mathrm{wt} \% \mathrm{NaOH}$ treated jute fibers. The glass transition temperature, $\mathrm{T}_{\mathrm{g}}$, of the unreinforced resin corresponding to the loss modulus peak was $101.2^{\circ} \mathrm{C}$ whereas that of the composites increased by nearly $28{ }^{\circ} \mathrm{C}$ on account of the restricted mobility of the resin molecules in the presence of the fibers. In the case of treated composites, the $\mathrm{T}_{\mathrm{g}}$ value showed a decreasing trend $128{ }^{\circ} \mathrm{C}$ to $125^{\circ} \mathrm{C}$ unlike the plain resin a tiny hump was observed in the loss modulus E, curves of all the composites around $166{ }^{\circ} \mathrm{C}$, which became broader and more prominent with the increase in the jute fiber content. Manikandan et al. [11] studied the tensile properties of short fiber-reinforced polystyrene composites using untreated and benzoylated sisal fibers and investigated the influences of fiber length, fiber content, fiber orientation. Variation in fiber length produced no considerable change in the modulus of the composites but gave maximum TS (25 MPa) at a fiber length of about $10 \mathrm{~mm}$.

Considering practical and technological importance of composites, in this study we have focused on synthesizing polyester resin-jute mat reinforced composites using a simple cold press molding method in order to understand the influence of $\mathrm{CaCO}_{3}$ filler and alkali treatment on their physical and elastic properties.

\section{MATERIALS AND METHODS}

\subsection{Raw materials}

The raw materials used for the samples are polyester resin, hardener, (methyl ethyl ketone peroxide 'MEKP'), jute mat, and fillers (calcium carbonate). Jute fabrics are obtained from a local market having $2.5 \mathrm{ft}$ width and length. The chemical composition of jute fiber is presented in Table 1. Raw jute fabrics were treated with $\mathrm{NaOH}$ solution to extract impurities from jute fibers, such as hemi-cellulose, lignin, aromatic acids, esters, etc. which might weaken the adhesion between fibers and matrix. Jute fibers were immersed into $0.5 \mathrm{wt} \%$ and $5 \mathrm{wt} \% \mathrm{NaOH}$ solution, for 24 hours at room temperature. Then, the fibers were washed with fresh water to neutralize the $\mathrm{NaOH}$ solution. These were dried at $100^{\circ} \mathrm{C}$ for 24 hours. 


\subsection{Sample preparation}

The Jute mat obtained was cut into $10^{\prime \prime}-8^{\prime \prime}$ pieces. A paper was placed on dried SS sheets. A mixture of polyester resin, filler and hardener was spread evenlyon SS sheets. Then jute mat was placed onto this resin. Again a mixture of resin was spread on the jute mat. The samples obtained from the above procedure were allowed to cure under a Weber press hydraulic machine. In compression molding, the polymeric materials and the fiber are subjected to heat and pressure in a single stroke, which was accomplished by using the hydraulic press with heated platens. Molding temperature and pressure was kept as high as $250{ }^{\circ} \mathrm{C}$ and $250 \mathrm{KN}$, respectively. The materials are placed into a die so as to fill the die. As the mold closes down under pressure, the material is squeezed or compressed between the two halves and compacted to the shape inside the die. The excess material flows out of the mold as a thin film. This film expelled out of the mold is known as the 'flash'. Under the influence of heat, the compacted mass get cured and hardened to shape. After completion of heating the mold is allowed to cool down and collected for characterization.

Table 1 Chemical Composition of jute fiber

\begin{tabular}{ll}
\hline Constituents & Amount (\%) \\
\hline Cellulose & $59-65$ \\
Hemicellose & $22-25$ \\
Lignin & $11-14$ \\
Pectine & 0.3 \\
Trains, protein, pigment, and inorganic materials & 0.7 \\
Wax and fatty mater & $1.9-2.5$ \\
Moisture & $10-11$ \\
\hline
\end{tabular}

\subsection{Characterization}

To evaluate the elastic properties of the prepared composites, tensile and flexural testing was performed bya universal testing machine [Hounsfield UTM 10KN; ASTM D-638-98] at a crosshead speed of $0.2 \mathrm{~mm} / \mathrm{min}$, keeping a gauge length of $0.05 \mathrm{~m}$. Tensile specimen was prepared according to (ASTM D-638M-91) [12] at a crosshead speed of $1 \mathrm{~mm} / \mathrm{min}$. Flexural specimen was prepared according to (ASTM D790M) [13]. At last five samples of each composition were used in the mechanical testing.

\section{RESULTS AND DISCUSSION}

\subsection{Physical properties}

\subsubsection{Water absorption}

Fig. 1 shows the effect of soaking time on water absorption (WA) of polyester-jute mat composite prepared by applying different loads. WA increases with soaking time and load except for composite of applied load $142 \mathrm{kN}$ where the WA increases up to 120 hours and after that it starts to decrease. For composite with load $83 \mathrm{kN}$ and $160 \mathrm{kN}$ WA linearly increases with time (140 hours). 


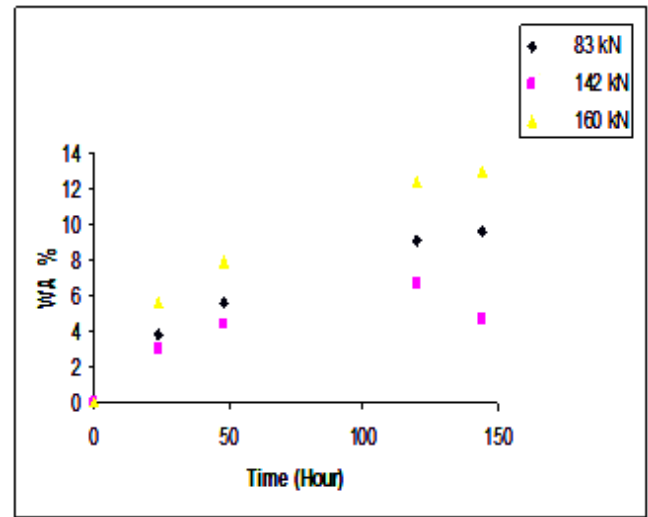

Fig. 1 Effect of soaking time on water absorption of polyester-jute mat composite for different loads.

The effect of soaking time on WA of polyester-jute mat composite for different concentration of $\mathrm{CaCO}_{3}$ with $0.5 \mathrm{wt} \%$ and $5 \mathrm{wt} \% \mathrm{NaOH}$ treated jute mat respectively are presented in Fig.2. For $0.5 \mathrm{wt} \% \mathrm{NaOH}$ treated jute mat composites, WA linearly increases with soaking time. With the increase of $\mathrm{CaCO}_{3}$ concentration the WA increases. The maximum WA was observed for $5 \mathrm{wt} \%$ addition of $\mathrm{CaCO}_{3}$ and after that, WA decreases. On the other hand for $5 \mathrm{wt} \% \mathrm{NaOH}$ treated jute mat composites, WA increases linearly with time and decreases with the addition of $\mathrm{CaCO}_{3}$. The cellulosic effect, the lignin effect and also presence of void spaces in the composites might be responsible for the increase of WA with time. In jute fiber reinforced polyvinyl chloride (PVC) film composites [14], WA increases with increasing time.
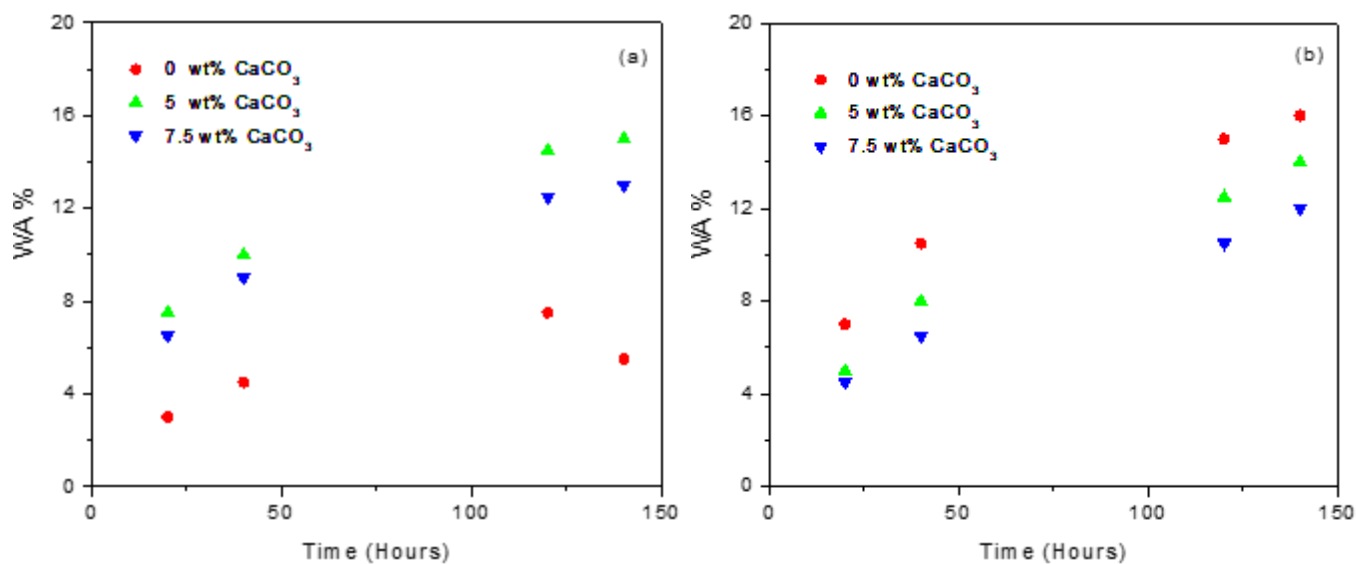

Fig. 2 Effect of soaking time on water absorption of (a) $0.5 \mathrm{wt} \% \mathrm{NaOH}$ treated (b) $5 \mathrm{wt} \% \mathrm{NaOH}$ treated polyester-jute mat composite for different concentration of $\mathrm{CaCO}_{3}$. 


\subsection{Elastic properties}

\subsubsection{Tensile properties}
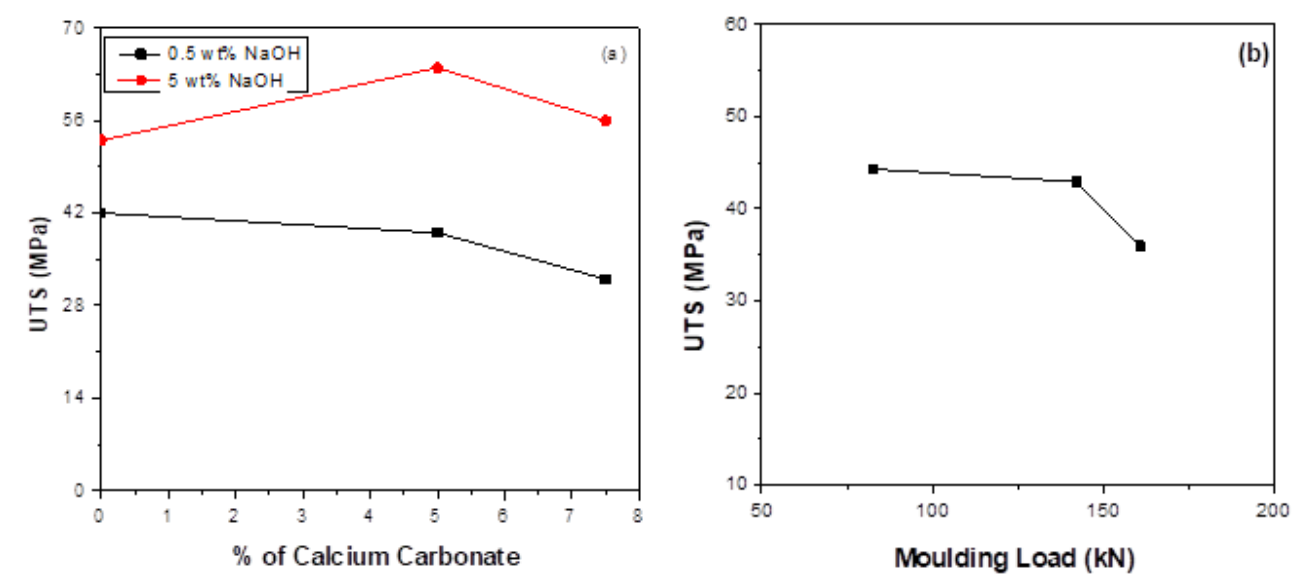

Fig. 3 Effect of (a) filler $\left(\mathrm{CaCO}_{3}\right)$ addition (b) moulding loadon UTS of polyester resin-jute mat composites.

Effect of $\mathrm{CaCO}_{3}$ filler on ultimate tensile strength (UTS) of polyester resin jute mat with $0.5 \%$ and $5 \% \mathrm{NaOH}$ treated composite is shown in the Fig. 3(a). It reveals that for $0.5 \mathrm{wt} \% \mathrm{NaOH}$ treated composites the UTS decreases with the addition of $\mathrm{CaCO}_{3}$. For $5 \mathrm{wt} \% \mathrm{NaOH}$ treated composites UTS increases with addition of $\mathrm{CaCO}_{3}$ up to certain percentage of filler and after that it decreases. The optimum filler addition is about $5 \mathrm{wt} \%$ for $\mathrm{CaCO}_{3}$. The $5 \mathrm{wt} \% \mathrm{NaOH}$ treated composites showed better TS than the $0.5 \% \mathrm{NaOH}$ treated composites. Alkali treatment generally increases the strength of natural fiber composites [15, 16, and 17]. A strong $\mathrm{NaOH}$ treatment may remove lignin, hemicellulose and other alkali soluble compounds from the surface of the composites to increase the numbers of reactive hydroxyl groups on the composites surface available for chemical bonding. So, TS of $5 \mathrm{wt} \% \mathrm{NaOH}$ treated composites is higher than $0.5 \mathrm{wt} \%$ $\mathrm{NaOH}$ treated composites. In jute fiber reinforced composites with polyester [18], higher TS was found for $5 \mathrm{wt} \% \mathrm{NaOH}$ treated composites than the $10 \% \mathrm{NaOH}$ treated composites. Effect of load on UTS of $0.5 \mathrm{wt} \%$ treated polyester jute mat composites is shown in Fig. 3(b). It displays that UTS decreases with increasing moulding load.

\subsubsection{Flexural properties}

Fig. 4(a) shows the effect of $\mathrm{CaCO}_{3}$ addition as a filler and $\mathrm{NaOH}$ treatment on flexural strength (FS) of the polyester jute mat composite. It is demonstrated that, the trends of the flexural properties are similar with the trends of TS. FS decreases with the addition of $\mathrm{CaCO}_{3}$ for $0.5 \mathrm{wt} \%$ $\mathrm{NaOH}$ treated composites but for $5 \mathrm{wt} \% \mathrm{NaOH}$ treated composites it increases up to certain percentage of filler addition and after that it decreases. The optimum filler addition is about $5 \mathrm{wt} \%$ for $\mathrm{CaCO}_{3}$. Reason of increasing FS, may be due to the fiber and matrix are well distributed up to $5 \mathrm{wt} \%$ filler addition. The FS of the composites with $0.5 \mathrm{wt} \% \mathrm{NaOH}$ treated composites decreases with increasing load as represented in Fig. 4(b). 

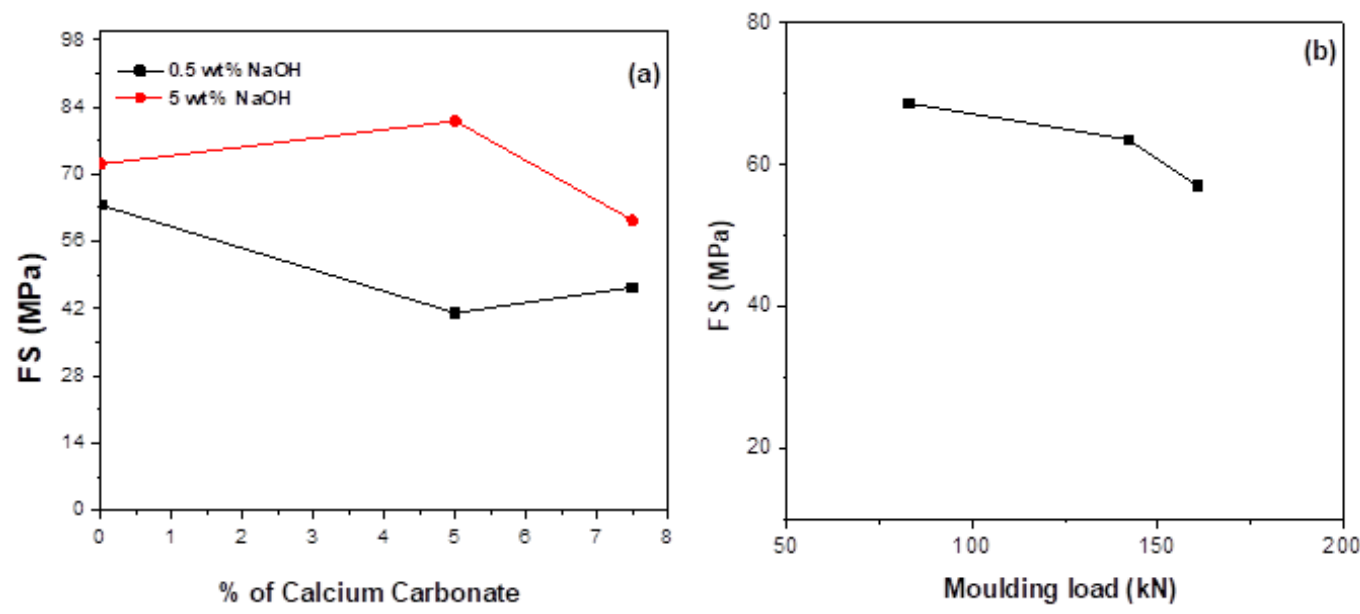

Fig.4 Effect of (a) $\mathrm{CaCO}_{3}$ filler (b) moulding load on flexural strength of polyester resin jute mat composites

Fig. 5 represents the effect $\mathrm{CaCO}_{3}$ filler on tangent modulus (TM) of $0.5 \mathrm{wt} \%$ and $5 \mathrm{wt} \% \mathrm{NaOH}$ treated polyester resin-jute mat composites, respectively. It shows that with the addition of $\mathrm{CaCO}_{3}$, $\mathrm{TM}$ increases for $0.5 \mathrm{wt} \% \mathrm{NaOH}$ treated composites and for $5 \mathrm{wt} \% \mathrm{NaOH}$ treated composites it increases up to a maximum value and then decreases. The maximum TM was observed for $5 \mathrm{wt} \%$ addition of $\mathrm{CaCO}_{3}$ filler. $10 \mathrm{wt} \% \mathrm{NaOH}$ concentration is reported as the ideal condition for maximum FS in sisal fiber reinforced polyester composites [19]. Therefore, the surface treatment of the fiber composites is considered significantly increases the adhesion characteristics and thereby improving mechanical properties. Similar improvements in the flexural properties of alkali treated natural fiber reinforced composites were reported previously [19, 20].

Fig.5b shows the effect of moulding load on tangent modulus of $5 \mathrm{wt} \% \mathrm{NaOH}$ treated jute composites. It reveals that TM decreases up to load $142 \mathrm{kN}$ and after that it increases.
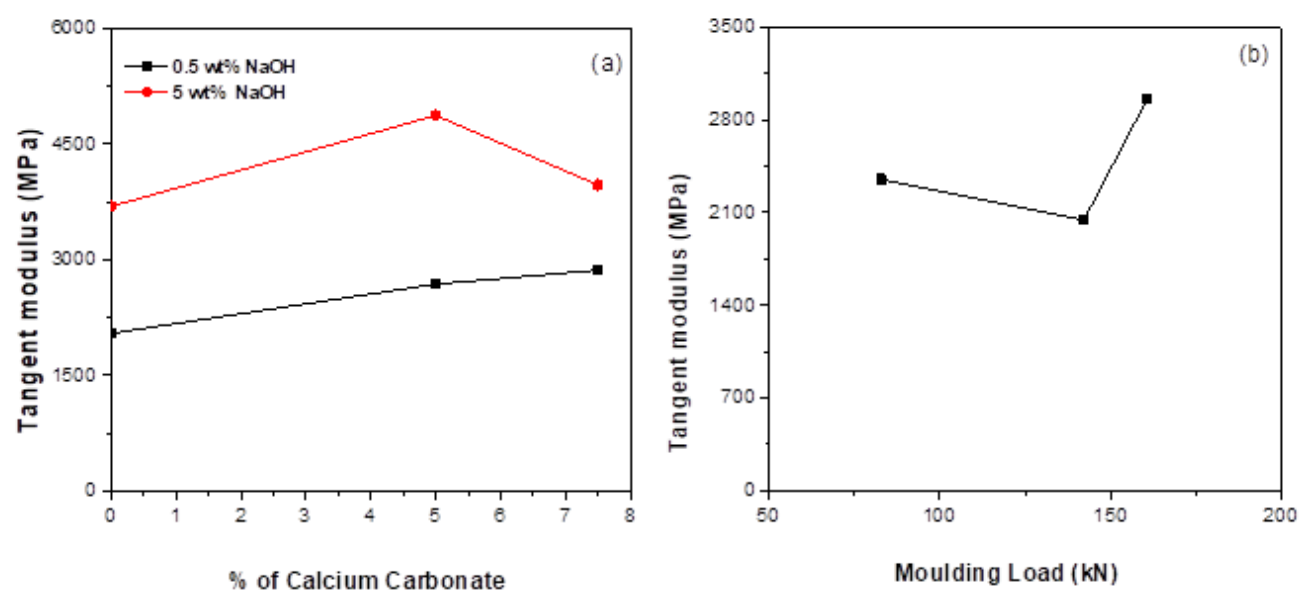

Fig.5 Effect of (a) $\mathrm{CaCO}_{3}$ filler (b) moulding load on tangent modulus of polyester resin jute mat composites 


\section{CONCLUSIONS}

WA increases with increasing load except for composite of applied load $142 \mathrm{kN}$. For $0.5 \mathrm{wt} \%$ $\mathrm{NaOH}$ treated jute mat composites WA linearly increases with the increase of soaking time and with of addition of $\mathrm{CaCO}_{3}$. The maximum WA was observed for $5 \mathrm{wt} \%$ addition of $\mathrm{CaCO}_{3}$. For the sample with filler addition more than that, WA decreases. On the other hand for $5 \mathrm{wt} \% \mathrm{NaOH}$ treated jute mat composites, WA increases linearly with time and decreases with the addition of $\mathrm{CaCO}_{3}$. The UTS and FS decreases with the addition of $\mathrm{CaCO}_{3}$ for $0.5 \mathrm{wt} \% \mathrm{NaOH}$ treated composites but for $5 \mathrm{wt} \% \mathrm{NaOH}$ treated composites UTS and FS increases with the addition of $\mathrm{CaCO}_{3}$ up to certain percentage of filler and after that it decreases. The optimum filler addition is about $5 \mathrm{wt} \% \mathrm{CaCO}_{3}$. With the addition of $\mathrm{CaCO}_{3} \mathrm{TM}$ increases for $0.5 \mathrm{wt} \% \mathrm{NaOH}$ treated composites and for $5 \mathrm{wt} \% \mathrm{NaOH}$ treated composites it increases up to a maximum value and then decreases. With increasing load UTS and FS decreases. From all of these results it can be concluded that increment of load and $\mathrm{CaCO}_{3}$ filler significantly affected different properties of the polyster-jute mat composites and $5 \mathrm{wt} \% \mathrm{NaOH}$ treated polyster-jute mat composites shows improved elastic properties in comparison to $0.5 \mathrm{wt} \% \mathrm{NaOH}$ treated composites.

\section{ACKNOWLEDGMENTS}

The authors are thankful to the authority of the Bangladesh University of Engineering and Technology (BUET) to provide financial support for this investigation. The authors are grateful to the Department of Materials and Metallurgical Engineering, BUET and Bangladesh Council of Scientific \& Industrial Research (BCSIR) to allow laboratory facilities for this research.

\section{REFERENCES}

[1] A. Kumar and A. Srivastava, Ind. Eng. Manage., 6 (2017) 234.

[2] M. K. Gupta, R. K. Srivastava, B. Himanshu, Inter. J. Fiber and Text. Res. 5(3) (2015) 30.

[3] S. Mohanty, A. K. Mubarak, A. Khan, S. Shaw, G. Hinrichen, J. Mater Sci. 35 ( 2000) 2598.

[4] M. A. Gafur and M. M. Rashid, $2^{\text {nd }}$ BSME-ASME International Conference on Thermal Engineering, 2-4 January, Dhaka (2004).

[5] A. K. Bledzki and O. Faruk, Appl. Composite Mater. 10 (2003) 365.

[6] A. K. Bledzki, and J. Gassan, Marcel Dekker Publishers, New Jersey, USA, (1997).

[7] J. Gassan and A. K. Blezki, Appl. Composite Maters. 7 (2000) 373.

[8] D. Ray, B. K. Sarker and N. R. Bose, Composite Part A 33 (2002) 233.

[9] M. N. Islam, J. Bagom, M. A. Gafur and A. H. Khan, Jahangirnagar University J. Sci., 30 (2007) 89.

[10] D. Ray, B. K. Sarkar, S. Das and A. K. Rana, Composite Sci. Technol. 62( 2002) 911.

[11] K.C. Manikandan, S. M. D. Nair and S. Thomas, J. Appli. Polym. Sci. 60 (1996) 1483.

[12] ASTM Designation; D 638-98, Standard Test Method for Tensile Properties of Plastics.

[13] ASTM (Reapproved 1991), Designation; F 417-78, Standard Test Method for Flexural Strength (Modulus Of Rupture) of Electronic- Grade Ceramics.

[14] A. Fardausy, A. Kabir, H. Kabir, M. M. Rahman, K. Begam, F. Ahmed, M. A. Hossain, M. A. Gafur, Inter. J. Adv. Res. Eng. Technol. 3 (2) (2012), 267. 
[15] T. V. Dieu, L. T. Phai, P. M. Ngoc, N. H. Tung, L. P. Thao and L. H. Quang, Solid Mech. Mater. Eng., 47( 4) (2004) 547.

[16] P. Gañán, and I. Mondragon, J. Mater. Sci. 39 (9) (2004) 1573.

[17] H. M. Rashed, M.A. Islam, and F. B. Rizvi, J. Naval Arch. Marine Eng. 8 (2006)31.

[18] A. Gopinath, S. Kumar, A. Elayaperumal, Procedia Eng. 97 (2014 ) 2052.

[19] M. M Hauwa and D. Benjamin, J. Polym.Text. Eng. 1(4) (2014) 31.

[20]. D. Ray, B. K. Sarkar, A. K. Rana and N. R. Bose. Bull. Mater. Sci., 24( 2) (2001) 129. 